\title{
REFLECTING ON VIOLENCE. ABOUT CLASSIC THEMES AND CONTEMPORARY ISSUES
}

\section{Maria Novella Campagnoli ${ }^{1}$}

\section{Abstract}

Arguing about violence means dealing with a classic theme which, however, today, with the complicity of new technologies, has taken on more nuanced faces and underground forms. Virtualized and dematerialized, today's violence occurs above all in that particular cocooning that is Cyberspace, forcing the jurist to deal with controversial issues ranging from cyber-terrorism to hate speech.

\section{Keywords}

Violence. Power of Right. Cyberspace. De-materialization and virtualization. Cyberterrorism. Hate-speech.

\section{Summary}

1. Premise. 2. Violence vs. Right and Power of Right. 3. Forms and faces of violence: between reality, virtuality and de-materialization. 4. Conclusions. 5. References.

\footnotetext{
${ }^{1}$ Lecturer at Roma Tor Vergata University - Italy.
} 


\section{PREMISE}

An inexhaustible and ambiguous question ${ }^{2}$, also because of its unique fascination, violence has always been the subject of critical reflection and investigation. The reason is due to the fact that it is a dimension that has to do with the human sphere, of which, in various ways and at different levels, it has intersected and still continues to intersect existence.

The history of man shows, in fact, a pendular oscillation ${ }^{3}$ and intermittent given by the alternation and almost rhythmic succession of two distinct moments, namely: the anti-violent courses and violent recourse ${ }^{4}$. Indeed, the courses, that is, those periods during which violence was the subject of a negative judgment, have always been followed by recourses: particularly convulsive and difficult times, in which violence was seen as a necessary energy, because cathartic and soteriological. An energy capable of wiping away those constraints and limitations which - according to certain reconstructions ${ }^{5}$ - would force and restrict the freedom of man, suffocating his will of power 6 .

${ }^{2}$ See MATHIEU 1989, 317-321.

${ }^{3}$ Cf. D'AGOSTINO 1983, X.

${ }^{4}$ On the alternation of courses and violent recourses, wide - and always current - the analysis of COTTA (1978, 27 ss.).

${ }^{5}$ I am thinking, for example, of BENJAMIN, for which the right - limiting human action - would in its own way be a form of constraint and an expression of violence $(2010,94)$.

${ }^{6}$ The reference to NIETZSCHE is evident here (see, in particular, 1977 and 1976). 
Paradigmatic, in this sense, the statement of Hegel, for which violence would represent the "wind movement that protects the sea from rot"7. Equally incisive, even the words of Sartre that - in the preface to the Damned of the land of Fanon - compares violence to the spear of Achilles: a spear that hurts but, at the same time, heals.

The myth $^{8}$, the literature and all art in general ${ }^{9}$ are undoubtedly among the most effective and eloquent witnesses of this alternation and of this continuous exchange of sentiments and judgments. And painting, with that synthesis, that clarity and that immediacy that are its own, is certainly no less. In fact, if it is true that the figurative arts are a tribute to beanty, it is also true that sometimes the visual representations have abandoned themselves to truculent and smug narratives of torments and sufferings. This is the case of the famous Scene of Torture by Eugène Delacroix, as well as the Heads of Executed by Théodore Géricault.

In other circumstances, the pictorial arts have turned into expressions of blame and harsh forms of condemnation of injustice and prevarication. Emblematic and quite powerful, both from an exquisitely iconographic point of view and from a content point of view, Susanna and the old men of Artemisia Gentileschi and - in another time - Frida Kahlo's A few little stab wounds. Decidedly crude works, of protest and denunciation. Both realized with feminine hand and in defense of the feminine.

${ }^{7}$ So, HEGEL 2006.

8 On the violence in the myth, it is essential the reference to - the now classical GIRARD's reflection (2008, 130 sq.).

9 About the relationship between art and violence, decidedly original and interesting analysis of AMATO MANGIAMELI 2012, 255. 
The contemporary age, with its many channels of communication conventional and non-conventional ${ }^{10}$ - It seems in its own way to add something new: now it aestheticizes violence, now it anesthetizes us with respect to it, now, again, it uses and feeds it. Just think of how the media are used to increase the tension that is generated around a news, just by resorting to images.

Images that, most of the time, are extemporaneous, devoid of any kind of filter, snatched directly from reality, devoid of devices and/or special technical expertise, and which, however, often - precisely by virtue of their imperfect truthfulness - produce an even stronger impact in the eyes of the spectator. Images that turn into excellent passe-partout of violence, fear and even horror ${ }^{11}$.

How can we not remember what happened during the attacks of 11 September 2001, when - quoting Baudrillard - the white magic of the images was combined with the black magic of violence. In a few minutes, on screens all over the world, the spectacle of terrorism was first increased and then even supplanted by the terrorism of the spectacle ${ }^{12}$. It is also impossible not to recall the 2015 attacks on the Bataclan and the headquarters of Charlie Hebdo. Violence reported by images or

${ }^{10} \mathrm{I}$ am thinking, in particular, of the advent of new Media and of the increasing diffusion of Social Networks that have revolutionized the communication and the diffusion of news. A constantly growing list of which Youtube, Facebook, Instagram, Pinterest, Linkdln, Twitter, Skype, Messenger, Viber, Telegram, Signal, Snapchat and Whatsapp are just some of the most well-known and popular.

${ }^{11}$ The relationship between images, violence and horror can be seen, among the many, see: TESTER 1997, 30-32; BOLTANSKI 2000; BAUMAN, 2015, 17-27; CAVARERO 2007. ${ }^{12}$ Here I repeat the words of BAUDRILLARD (2002, 39-40). In some ways similar to the reconstruction of Baudrillard, cf. DEBORD 1967. 
amateur videos, made with mobile phones and disclosed directly by those who were present in the first person.

Although it has to do with different events, cannot be easily forgotten even another image (these days and particularly close to the writer): that of the long and mute procession of vans of the army, departed from the city of Bergamo and Lombardy, along with the many coffins of the victims of Covid-19. A very violent narrative that, although it has nothing to do with belligerent actions, has however placed Italy, Europe and the other States, in the face of an unexpected and very alarming theater of death. A scene in which violence dominated, so to speak, inapparent that, however, has solidified and took shape precisely in the vision and thanks to the vision itself ${ }^{13}$.

Beyond the breadth and cyclicity of the question, it is interesting to underline that today's violence takes on unusual faces and unexpected declinations. The reason is given by the fact that violent behaviors are no longer realized only in the real world and off-line, but also online and, that is, within that particular de-territorialized and de-centralized space $^{14}$ that is the cyberspace ${ }^{15}$.

And if, in some cases, the criminal conduct carried out in the World Wide Web re-proposes - albeit with different methods and tools -

${ }^{13}$ I use - and adapt - the concept of inapparent violence, for the truth originally elaborated in regard of literature (cf. FALCO 2016).

14 Concepts introduced several years ago by LÉVY (1997, 9-14), among the first to emphasize that the traditional space (that of places, cities, nations, limits and borders) was, by now, supplanted by an absolutely new space, unlimited both from a spatial and temporal point of view and, for this very reason, marked by simultaneity and ubiquity.

15 In the Italian panorama, one of the first ever to reflect on cyberspace, AMATO MANGIAMELI 2000. 
crimes already known and disciplined, in other cases, instead, envisage completely new cases, in respect of which it is not sufficient to have recourse to an adaptation and/or an extension of the previous legislation, but an ad hoc regulatory intervention is necessary ${ }^{16}$.

Here, too, the need to reflect again on violence, starting from the structural and onto-phenomenological analysis, and then turn attention to some of the most controversial and current violent conduct that arise and develop in that sea that is the Net ${ }^{17}$; a sea in which are concealed even dark and hidden bends, like the Deep ${ }^{18}$ and Dark $W e b^{19}$.

\section{VIOLENCE vs. RIGHT AND POWER OF RIGHT}

To confirm the well-known Heideggerian statement, according to which the house of the Being and the truth of the Being would be placed

${ }^{16} \mathrm{I}$ am thinking, in particular, of what happened in Italy, the day after the adoption of the Budapest Convention of 23 November 2001, when there was the application of a dual strategy: the adaptation and adjustment of the existing regulations, on the one hand, and the introduction of specific rules on the other.

${ }_{17}$ On the similarity between the Web and the sea, cf. AMATO MANGIAMELI (2000, 2015 and 2020, in part. 26).

18 It is not marginal to remember that, differently from the Surface $W e b-$ that is from the c.d. surface Internet to which everyone has access (and access) continuously and daily the Deep $W e b$ represents that part of the Net (equal to 89-96\%), which is not indexed by search engines and is not traceable or reachable through Google.

19 A further subset of the Deep Web, the Dark Web is composed of all those pages with a domain ".onion" located on servers using the protocol "Tor". A protocol that was initially developed by the United States Department of Defense to allow anonymous and secure communications, but which, today, is home to the black market, where you can find drugs, weapons and even hire killers to kill someone. 
inside the language ${ }^{20}$, in the approach and understanding of violence, a first fundamental indication can be taken from the etymology.

It has the same root of the verb violate (from the Latin violo, literally: maltreat, insult, dishonor, profane) and the French word viol (rape), violence immediately manifests that intrinsic negative value that makes it structurally incompatible with the right itself. This is a reading that has already emerged and made its way already from philosophy and classical literature.

Expression of that arrogance and that insolence that induces men to contravene the will of the gods, violence - in the context of Greek culture - has been, in fact, considered as the antithesis of the vouos

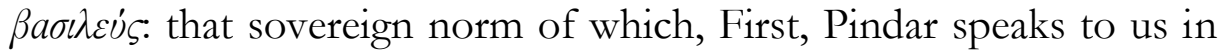
the Nemee ${ }^{21}$.

And, with reference to the contrast between violence and vouos (authentic right) the writings of Aristotle are decisive ${ }^{22}$. Here, in fact, violence $(\beta \iota a)$ is associated with the absence of laws (avoura), the lack of justice $(a \delta \iota x \iota a)$, and the prevalence of pride $(\nu \beta \varrho \iota)^{23}$. Pride (or, more literally, arrogance) that - as we read especially in Plato - distinguishes the figure of the tyrant ${ }^{24}$, whose precepts and rules are the result of voluntary imposition and coercion alone ${ }^{25}$.

${ }^{20}$ HEIDEGGER 1978, 74 e 81.

${ }^{21}$ See PINDARO (2010, fr. n. 169).

${ }^{22}$ Cf. 2016, 1313a.

${ }^{23}$ With regard to the distinction between $\beta \iota a$ and $u \beta \varrho \iota \varsigma$, see the in-depth, and always timely, analysis proposed by D'AGOSTINO (1983, 21-34).

${ }^{24}$ Cf. 2009, 291c e 309a; 1997, 361b, 413b, e 569b.

${ }^{25}$ Precepts and provisions that - precisely because they are based on the will of those who hold power and lack a strong foundation (in accordance with justice) - have generated and 
Unregulated, non-dialogical ${ }^{6}$ and non-co/existential ${ }^{27}$, because the result of an absolutization of the ego and of an egotist vertigo ${ }^{28}$, violence is first and foremost an activity-against. Namely, an activity that is the exact opposite of the right that is an activity for the other - is oriented to living against the other, that is to the prevarication ${ }^{29}$ and the reification of others.

Various aspects that help to identify and distinguish the violent gesture $^{30}$, among these:

- the immediacy, due to the fact that the violent act is a gesture of impetuousness, which is unleashed in a sudden way, without there being room for reflection and/ or mediation between will and action;

- the discontinuity, since violent action is destined to exhaust itself;

- the disproportion with respect to the aim pursued, since, proceeding in an irrational and blind way, the act of violence never succeeds in reaching the exact effect set;

generate forms of dissent. How not to remember the famous appeal to heaven of Antigone, narrated in the tragedy of the same name (SOPHOCLES, 1952). Equally significant and worthy of note are also the many other forms of dissent that, in the course of history, have gradually alternated. Think of the right of resistance (LOCKE, 1960, II, 228), the right of pen (KANT, 1956), non-violent resistance and civil disobedience (GANDHI, 1996, 168; 1997, 199). 26 " $\mathrm{Bia}$ is mute: she acts, but does not speak, because she is a force devoid of logos, a constraint that does not feel the need to justify itself with arguments of a general nature" (CERRI 1975, 20-21).

${ }^{27}$ See COTTA 1991, 101 ss.

${ }^{28}$ On the vertigo of the "IO", the referral to KIERKEGAARD (1947) is mandatory.

${ }^{29}$ Regarding the relationship between violence/prevarication, see CLAUSEWITZ 1943, chap. 1.

${ }^{30} \mathrm{I}$ recall here the characteristics of the violent action as identified by COTTA $(1978,69)$. 


\section{Maria Novela Campagnoli IREFLECTING ON VIOLENCEI ISSN 2675-1038}

- the non-durability, due to the inability of violence to result in a stable and permanent condition;

- the unpredictability, which characterizes and permeates the whole parable of violence action: the initiation, the development and the outcome;

- the depersonalization, identified by the loss of subjectivity ${ }^{31}$ and identity that affects both the victim and the agent ${ }^{32}$.

To these characteristics, however, we add another, further and decisive, namely the absence of the measure, thanks to which it is possible to distinguish violence both from the force, both from the sanction ${ }^{33}$, as the proper force of law.

In fact, unlike the act of violence - which is always devoid of $\mathrm{it}^{34}$ - the act of force is endowed with the measure. Measure, which is present in all three of its modes: in the form of an internal measure (since the act of force is in itself self-measured), of an external measure (because, also externally, the action conforms to measure) and, last but not least, also in the form of a final measure (because the act of force, which in itself is a measuring act, is aimed at restoring that equilibrium that has failed).

${ }^{31}$ From this point of view - as WEIL pointed out - the subject gives in to "[...] a naked and vegetative selfishness. A selfishness without IO” (1962, 35-36).

32 About the depersonalization and loss of identity, as a direct consequence of the violent action, interesting and noteworthy observations of VIRILIO $(1986,64)$ and MILGRAM (2003, 10-11). In particular, Milgram introduces the concept of countermorphism, to indicate the loss of anthropological characteristics typical of man. A loss that would involve both victims and agents (executioners).

33 On the sanction tout court (positive and negative) cf. D'AGOSTINO 1999, 112 ss.; 2010, 217-218. With specific regard to punishment, however, significant observations of AMATO MANGIAMELI 2019a, 69-98.

${ }^{34}$ See COTTA 1978, 75-98. 
And it is for this reason, that is, for the presence of the measure, that the force - although it can be abstractly traced to the genus proximum of the activities-against (that is to say to those activities that are realized regardless of the will of the subject destined to suffer its effects) - is structurally and teleologically compatible with the law.

Socionomical ${ }^{35}$ and called to ensure the Mitsein ${ }^{36}$ - or that living-with-the other that is the primary condition of human existence itself ${ }^{37}$ - the right not by chance can also be defined as a rule of force $e^{38}$ and as non-violent paradigm ${ }^{39}$ of settling disputes.

Hence, the link between law and sanction ${ }^{40}$. As a necessary and inescapable consequence $^{41}$ of the offence and, more generally, as a measured,

35 Unlike all voluntary, formalistic and legalistic readings that look to the law as the result of the beteronomic creation of an external legislator, regardless of the existential needs of the individual (see, for example, ZAMPERINI 2003, XXVI), the onto-phenomenological perspective makes it possible to highlight the socionomic perspective of law, since it is closely connected with the anthropological dimension of man, and conforms to the fundamental ontological and existential needs of the human being, which being in relation with the other (COTTA, 1991).

${ }^{36}$ Essential, the reference to the reconstruction of HEIDEGGER (2011), which addresses the problem of relational dynamics and the ontological-existential structure of the human being whose being-there translates into a being-with.

${ }^{37}$ See PIOVANI 1972, 41. In analogy with this perspective CAPOGRASSI, for which the law constitutes a way of human experience $(1962,20)$.

${ }^{38}$ Here I take again the note, and always effective, expression of BOBBIO 1970, 126.

${ }^{39}$ On the model of Western non-violence founded on the right referral to D'AGOSTINO, 2000, 233 sq.

${ }^{40}$ Quite significant, it is the etymological root of the term which, being traceable to the Latin verb sancire, may take on the meaning of agreeing, consecrating, guaranteeing, and even that of existing (cf. TACITO 2017, XXVII, 10).

${ }^{41}$ Interesting, on the point, what observed by BRANDÃO 2006, 195-213; 2019. 
symmetrical and proportionate response ${ }^{42}$, that the right gives (and cannot not give.) to the alteration of the relational equilibrium ${ }^{43}$.

A response, the sanctioning one, whose effectiveness - as already clarified Beccaria - does not rest on the affliction (in the sense of physical and material suffering), but, rather, on objectivity, certainty and mildness, as an expression of moderation, weighting, tertiary and, ultimately, of justice ${ }^{44}$. Not surprisingly, in all the available representations, the justice, besides being blindfolded (because super partes), carries in one hand the scales (symbol of balance and measure) and in the other the sword (sign of strength and that force that is expressed in the punishment).

And it is in this perspective that, in the narration of Aeschylus, Zeus punishes (and must punish) Prometheus, guilty, for too much love and too much friendship towards men $(\delta \imath \alpha \tau \eta v \lambda \iota \alpha \nu \varphi \imath \lambda o \tau \eta \tau \alpha \beta \rho o \tau \omega \nu)^{45}$, to have disregarded the divine provisions, going beyond the measure of justice and law $(\pi \varepsilon \rho \alpha \delta l \kappa \eta)^{46}$.

42 The proportion of penalties and the need to be certain and at the same time mild ${ }^{43}$ With regard to the structural elements of the law that, by force of things, can only replicate in the penalty, it is obligatory to refer to the classic reconstruction of COTTA $1979,106 \mathrm{sq}$.

44 "The certainty of a punishment, although moderate, will always give a greater impression than the fear of another more terrible, united with the hope of impunity; because the evils, even minimal, when they are certain, always frighten human souls [...]. The countries and times of the most atrocious supplications were always those of the most bloody and inhuman actions, since the same spirit of ferocity that guided the hand of the lawgiver, held that of the parricide and the assassin. To the extent that supplications become more cruel, human souls [...]" (BECCARIA 1974, cap. XXVII).

45 Thus, Hephaestus: "Thou, God, without fearing the wrath of the gods, thou didst bestow upon men the attributions which thou didst bestow upon them" (29-30).

${ }^{46}$ See KERÉNYI 1979, 234-235. 
A duty - to punish ${ }^{47}$ - to which the right of the offender corresponds ${ }^{48}$ to be punished. That is, the right of the offender to atone for his guilt through punishment, so that he can be reintegrated into the system of freedoms ${ }^{49}$.

Duty to punish/Right to be punished, that must always be the object of attention and application also with reference to the many and always new web-crimes ${ }^{50}$. Conduct which - although carried out on the Net - still require regulation and adequate legal responses ${ }^{51}$. Only in this way, in fact, can we avoid the risk that the Net could become a sort of legal Far West and, that is, in an area of shadow of the law itself ${ }^{52}$.

\section{FORMS AND FACES OF VIOLENCE: BETWEEN REALITY, VIRTUALITY AND DE-MATERIALISATION}

3.1. In a general way - referring to the partition proposed by Ballesteros - three different forms of contemporary violence can be identified:

${ }^{47}$ It is interesting to note that this duty rise - even in non-legal contexts - from the reconstructions proposed by VON BALTHASAR $(1982,80 ; 1993,19)$ and by LÉVINAS (1986, 183).

48 HEGEL 2006, 209-230.

${ }^{49}$ Emphasizes with the usual effectiveness MATHIEU: "The purpose of the sentence is to formally restore justice, and to reinstate in the system of freedoms the wills that have emerged from it" (2008, 210-213).

${ }^{50}$ For further information on web-crimes, cf. AMATO MANGIAMELI, SARACENI 2019c; BALKIN 2016; ALISDAIR 2015; MARAS 2015; McQUADE 2014.

51 On the difficulties of criminal law in regulating criminals behaviours on the Internet, see HILDEBRANDT 2015; ZICCARDI, 2013; EDWARDS, WAELDE 2000.

52 Cf. ZICCARDI, 2017, 7-12. 


\section{Maria Novela Campagnoli IREFLECTING ON VIOLENCE I ISSN 2675-1038}

i) economic violence, which, being based on the overvaluation of property, money and material goods in general, leads to a reduction of attention and respect for the person and life;

ii) the playful one, expression of the progressive loss of moral values and of that narcissism that - at the individual level - is expressed in consumerism, hedonism, aestheticism, permissiveness, while - at the collective level - is manifested in politicism or fanaticism;

iii) and the political one, which is always imbued with a strong ideological component and which can take the form of totalitarianism or terrorism ${ }^{53}$.

Although it is shared and appreciable, this tripartition does not account for a recent element that, transversally and at different levels, can trace itself in all violent behaviors and that is constituted by the virtualization of the action and even the notion of violence.

Mind you, what you see and want to emphasize here is not a mere change of means, strategies and/ or objectives, but something conceptually different, broader and radical. It is a change that besides involving and modifying simultaneously tools, modes and objects affected - it goes to redesign above all the outlines of the violence itself.

It is a transformation similar to that which, since the end of the $90 \mathrm{~s}$, marked the transition from paper to computer, determining the

${ }^{53}$ BALLESTEROS 2006, 20 ss. 
liberation from body support ${ }^{54}$. A de-materialization, which is particularly evident especially when we look at terrorism.

3.2. If it is true that violence tout court since long time no longer identifies itself, exclusively, with what is its most traditional meaning of vis corpore corpori afflicta, it is equally true that, among the various manifestations of contemporary violence, Terrorism is certainly the one that has been most emancipated in the sign of virtuality and immateriality and that, developing an increasingly intense relationship with new technologies, has renewed and gradually reconfigured its image.

More specifically, in a first phase, Information and Communication Technology were used mainly in an instrumental way, as a resonance box $^{55}$ and as multiplier force ${ }^{56}$, exactly as it happened in 2001 during the attacks on the World Trade Center and the Pentagon ${ }^{57}$. While, in a second phase, ICT have become the ideal cocooning of terrorism

54 On this point, see AMATO MANGIAMELI 2015, in part. 266-270.

55 About the relationship between violence, terrorism, communication and media, cf. of the first, SCHMID, DE GRAFF 1982. On this point, cf. also, among others, LOMBARI, ALVANOU, FONIO 2009.

56 That is, as a force capable of amplifying the reverberation of terrorism itself, transforming a local event - circumscribed in time and space - in a global event that knows no time or space boundaries. On the inherent relationship between the use of new technologies and the overcoming of temporality and spatiality I refer to what has already been pointed out, several years ago, by VIRILIO 2000, 7. Particularly interesting are also the observations of DERRIDA 2003.

${ }^{57} \mathrm{On}$ the analysis of suicide terrorism in the aftermath of the attacks of 11 September 2001, I would like to refer to what I had the opportunity to point out in the past and on other occasions (CAMPAGNOLI 2015 and 2017). 
itself ${ }^{58}$. That is, in the privileged habitat within which the terrorist operation is not simply conceived and planned but is also developed and carried out.

Reason is soon spoken and, in some ways, is even intuitive. The electronic cocoon - of which the screen is in its own way effigies - by virtue of its ability to transmit and share information, and its intrinsic and simultaneous ability to conceal pitfalls and hide actions and intentions, lends itself in a particularly functional way to the realization of terrorist activity. Activity which, as it has always been and is in itself mimetic ${ }^{59}$, in recent years, has become even more evanescent, incorporeal and viral. An incorporeality and virulence, which are not merely theoretical and that derive not only from the capacity of terrorism to spread capillary on a global scale, but which are also factual and absolutely concrete.

58 More specifically Internet plays a leading role, which - thanks to the many software and various applications available - reveals itself as a mine of information and resources for terrorists. Think, for example, of Mujabideen Secrets (developed by Al-Quaeda since 2007), as like a Tashfeer al-Jawwal, Asrar al-Ghurabaa and Amn al-Mujahid. Cryptographic platforms and programs that terrorists use to encrypt their telematic communications. See, among others, TETI 2015a; 2015b.

${ }^{59} \mathrm{On}$ the subject of mimicry cf. VIRILIO 1986, 64. Moreover, on this point, it is interesting to point out that mimicry - together with the asymmetry, the irregularity, the political commitment and the particular relationship with space (telluric and/or aerial) - is one of those characteristics that allow the figure of the terrorist to be assimilated to that of the partisan (SCHMITT 2008, 26-29). 
After all, like most of the gyber-attack $k^{60}$, the terrorism today is realized between the folds of the Deep and, above all, of the Dark Web ${ }^{61}$, through the use and dissemination of malicious programs ${ }^{62}$, like virus, trojan, rootkit e spyware. A conduct that, among other things, also involves the realization of a whole series of further and collateral criminal cases, such as, for example, phishing ${ }^{63}$, pharming ${ }^{64}$; sniffing ${ }^{65}$; craking or the dark-side hacking 66 .

Otherwise said and in short, between connections and interconnections, that global-media terrorism ${ }^{67}$, that characterized the attacks of the beginning of the year 2000, seems to have now given way to gyber-terrorism ${ }^{68}$. Variant in which the technological dimension -

${ }^{60}$ Genus which, in truth, covers a wide range of cyber threats, whether carried out by individuals or by national and transactional criminal organizations. Among these: the cyberactivism (i.e. the attack carried out for ideological, political, economic reasons, and aimed at damaging a computer system or obtaining information); the gyber Espionage (i.e., activities aimed at the removal of industrial secrets, military projects and/or documents, secrets of institutions or bodies); cyber war (which represents a real conflict between nations, in which the forces in the field are fighting trying to break down the barriers of protection and technological security).

${ }^{61}$ In particular, in the dark market, where it is possible to buy weapons or proceed to the realization and exchange of counterfeit documents.

${ }^{62}$ Regarding the use of malicious programs, see AMATO MANGIAMELI 2020.

${ }^{63}$ Unlawful conduct that consists in pretending to be a bank or a financial institution to subtract passwords and confidential data.

${ }^{64}$ Behavior aimed at constantly monitoring and spying on users.

65 That is the interception of communications and data exchanged between two or more users.

${ }^{66}$ The insertion into another user's computer system and its subsequent destruction.

${ }^{67}$ On this point, I would like to defer to what I observed elsewhere in CAMPAGNOLI 2015, 40.

${ }^{68}$ See, among many, MAROTTA, ANTINORI 2007, 19 sq.; PINO 2013, 429; MEHAN, 2014; CHEN, LEE, 2014; COHEN 2016. 
as well as permeating every stage of the attack (the finding and dissemination of information and know-how, the dissemination of propaganda messages or denigration, as well as the affiliation and recruitment of new cells) - also identifies the target towards which the terrorist action itself is oriented and directed.

Born of the union between terrorism and that peculiar non-place 69 virtual that is the net, the cyber-terrorism is therefore characterized by a double aspect: that of being realized with digital technologies and that of being directed to digital technologies and, in particular, to hit the computer equipment (pc, networks, cloud and storage spaces) used for the transmission of communications and information, especially at institutional and governmental level ${ }^{70}$.

Hence, de-materialization and virtualization ${ }^{71}$ almost of the total terrorist violence itself. A violence that until a few years ago was spectacular, overexposed and, to use an effective neologism, almost consumer displayed ${ }^{72}$, and that now, into Big data and Big data analytics ${ }^{73}$ age, goes to strike and to use precisely those disembodied and volatile goods identified by the information and data ${ }^{74}$.

${ }^{69}$ With regard to the non-places and, in an articulate manner, the c.d. dusk of the places, it is obligatory to refer to VIRILIO 2004, 104 sq.

${ }^{70}$ Cf. SABELLA 2017, 139-176.

71 See BAUDRILLARD 1981.

72 On the consumer displaying of violence through the media cf. CODELUPPI 2007.

73 See TALIA 2018; AMATO MANGIAMELI 2019b, 107-124.

74 Data that, are constantly growing and that represent a "source of economic power", a new form of value that changes markets and relations, not only those between citizens, but also those between organizations and governments (MAYER-SCHÖNBERGER and CUKIER 2013, 18-22. 
The result, it is clear, is a profoundly different terrorism: undoubtedly less blatant and not at all bloody, but more submerged, much rarefied and, at times, even impalpable. Fatal Strategy ${ }^{75}$ that into Synopticon ${ }^{76}$ became white, even transparent, and yet - not for this reason - less consistent, insidious and deceptive ${ }^{77}$. Ungaretti would say: "No violence exceeds that which has silent and cold aspects." 78 .

3.3. Mutatis mutandis, this same transformation in the sign of virtualization and dematerialization can also be traced in the bate

75 Obvious, here, the reference to the homonymous work of BUDRILLARD, as well, to his words that - in some ways - may also be used to describe the transition from terrorism to cyber-terrorism: "Au début, ily avait le secret, et c'était la règle du jeu des apparences. Puis il y a eu le retiré, et c'était la règle du jeu de profondeur. Il y a enfin l'obscène, et c'est la règle du jeu d'un univers sans apparences et sans profondeur - d'un univers de transparence. Obscénité blanche" (1983).

${ }^{76}$ On the net as Synopticon that does not force but seduces people to look (and let themselves be looked at), see BAUMAN 2007, 59-60.

77 As Advise also EUROPOL 2019. In addition, on problems relating to the suppression of such practices, ex multis, CADOPPI, CANESTRARI, MANNA, PAPA 2019; MOSLEMZADEH TEHRANI, ABDUL MANAP, TAJI, 2013, 207 ss.; FLOR, 2017, 325 ss.

${ }^{78}$ UNGARETTI 2016, 131. 
speech $^{79}$. And that is, with regard to said hate speech ${ }^{80}$, which involve the use of disparaging expressions and contempt, with the aim of spreading and inciting intolerance and hatred towards certain

79 It is important to remember that, to date, there is no unambiguous and universally shared definition of hate speech. A first notion can be found in the International Convention on Civil and Political Rights of 16 December 1966, in which Article 20 reads: "1. Any propaganda for war shall be prohibited by law. 2. Any advocacy of national, racial or religious hatred that constitutes incitement to discrimination, hostility or violence shall be prohibited by law". A second source of great defining interest is the Council of Europe Recommendation on hate speech, n. 20, 30th October 1997.

In the European context, efforts have been made to identify and delimit borders in a number of significant ways. At first, one cannot but remember the Council Framework Decision 2008/913/JHA on combating certain forms and expressions of racism and xenophobia by means of criminal law. Noteworthy, even the Recommendation of the Committee of Ministers to member States CM/Rec(2014)6 - Guide to Human Rights for Internet Users - in which it's written: “"hate speech' shall be understood as covering all forms of expression which spread, incite, promote or justify racial hatred, xenophobia, anti-Semitism or other forms of hatred based on intolerance, including: intolerance expressed by aggressive nationalism and ethnocentrism, discrimination and hostility against minorities, migrants and people of immigrant origin" (point n. 42). Equally significant and important, the most recent definition provided by European Commission against Racism and Intolerance, which further extended the category of hate speech to include speeches that appear, at first glance, politically correct: "Considering that hate speech is to be understood for the purpose of the present General Policy Recommendation as the advocacy, promotion or incitement, in any form, of the denigration, hatred or vilification of a person or group of persons, as well as any harassment, insult, negative stereotyping, stigmatization or threat in respect of such a person or group of persons and the justification of all the preceding types of expression, on the ground of 'race', color, descent, national or ethnic origin, age, disability, language, religion or belief, sex, gender, gender identity, sexual orientation and other personal characteristics or status" (ECRI 2015, 3).

${ }^{80}$ For the control of the conduct, see PITRUZZELLA, POLLICINO 2020; McGOWAN 2019; PINO 2008, 287 sq. 
categories of individuals, certain groups or certain minorities (ethnic, religious, cultural, linguistic, etc.) ${ }^{81}$.

First of all, it must be said that, as in the case of terrorism, even with the hate speech, we are in front of a typology of violence that - as underlined by the poetic verses of Wislawa Szymborska - is decidedly dated and able to feed and to regenerate itself continuously

"See how efficient it still is,

how it keeps itself in shape

our century's hatred.

How easily it vaults the tallest obstacles.

How rapidly it pounces, tracks us down.

It is not like other feelings.

At once both older and younger.

It gives birth itself to the reasons that give it life.

When it sleeps, it's never eternal rest.

${ }^{81}$ It is interesting to underline that, until the years 90 's, the manifestations of hatred had to see - prevalently - with the racial diversities, with the antisemitism or with the denial. Only recently, in fact, the attention has shifted to other religious minorities (especially Muslims, increasingly subject to threats and discrimination), as well as women, GLBT people (gay, lesbian, bisexual, and transgender), disabled and sometimes, even on the elderly. 
And sleeplessness won't sap its strength; it feeds it [... '>82.

It is a form of violence that, although it can be expressed in absolutely different ways (in oral form, written, but also through images, symbols...), is always distinguished by the simultaneous presence of three essential factors: $i$ ) the clear and explicit will to foment hatred; ii) the implementation of a real incitement, suitable to trigger acts of hatred and violence towards the victim(s); iii) the resulting acts of violence or discrimination ${ }^{83}$.

Beyond these elements, we cannot help but underline that, following the encounter and synergy with new technologies, and especially with telematic platforms and apps, hate speech has greatly increased its offensive. The reason is soon told. If it is true that - in the transition from off-line to on-line conduct - the aim remains the same. and, that is, to hit those who are perceived as different and absolutely Other (i.e. because he's a foreigner, because he's black, because he's poor, or because he's a homosexual, woman, disabled, etc. $)^{84}-$ it is also true that once they are lowered into cyberspace, hate speech acquires a much higher degree of hostility and aggressiveness. If only because, taking advantage of that simultaneity and ubiquity that is proper to the virtual dimension, they manage, not only to spread in a very short time, but also to replicate and multiply exponentially.

82 See SZYMBORSKA 2009.

${ }^{83}$ See ZICCARDI 2018, 40.

84 With regard to the sense of hostility that accompanies the meeting, the Other (different/foreign) must be referred back to ENGELHARDT (1999, 35-44, 58-59) who, for the first time, presents the figure of the moral stranger, the object of fear, hatred and exclusion. 
As proof of this, it is enough to think of the ease with which even a single hater, with a mechanism that is mirror to that used by influencers for the promotion of products and trends, can be able to drag many more, triggering an escalation, in which millions of rants and racist or xenophobic expressions are channeled all together, generating a single immense flow of hatred and violence that goes to hit the victim(s) predesignated $(\mathrm{s})^{85}$.

In addition, it is important to point out that to have had - and to have - a leading role in the transition from hate speech off-line to bate speech on-line is not so much the World Wide Web tout court, how much more that innate propensity to comments and that eagerness for consensus and like that is found in the Social Networks ${ }^{86}$ and that is typical of these platforms ${ }^{87}$.

And it is for this reason that social today are the main carriers ${ }^{88}$ of said information disorder ${ }^{89}$. That is, the main channels of diffusion of all those manipulated and/or distorted communications ranging from disinformation ("information that is false and deliberately created to harm

${ }^{85}$ See, ZICCARDI 2016.

86 See COLOMBO 2013, 138 ss.; RIVA 2016; LOVINK 2016; DEL VIGNA, CIMINO, DELL'ORLETTA, PETROCCHI, TESCONI 2017, 86-95.

87 About the appeal of the Social Network and that "mipiacismo", I refer to what I recently pointed out (CAMPAGNOLI 2020, 261).

${ }^{88}$ Precisely in view of the particular role of social networks (such as new media available to the masses) in the dissemination of the hate speech, significant and important adoption - in May of 2016 - of the Code of Conduct on countering illegal hate speech online, subscribed by Facebook, Twitter, YouTube and Microsoft. Code to which, during 2018, Instagram also subscribed, Google+, Snapchat and Dailymotion, and who, in 2019, joined Jeuxvideo.com. ${ }^{89}$ See Information disorder: Toward an interdisciplinary framework for research and policy making Council of Europe Report DGI(2017)09. 
a person, social group, organization or country") $)^{90}$, to mis-information ("information that is false, but not created with the intention of causing harm") 91 , till mal-information ("information that is based on reality, used to inflict harm on a person, organization or country") ${ }^{92}$.

Mal-information of that the hate speech is without doubt the most extreme and damaging manifestation. A slander charge of violence that recalling The Barber of Seville - looks like to:

"little breeze [...] gentle zephyr [...]

which insensibly, subtly, [...] sweetly [...]

commences to whisper.

[A little breeze] sottovoce, sibilant,

it goes gliding, it goes rambling. [...]

gathers force little by little

$[.$.$] runs its course from place to place [. .$.$] ".$

and which, as Don Bartolo points out, can lead to terrible consequences and even tragic results.

90 Ivi, 20.

${ }^{91}$ Ibidem.

${ }^{92}$ Ibidem. 
"Finally with crack and crash

it spreads afield, its force redoubled [...]

And the poor slandered wretch

vilified,

trampled down sunk beneath the public lash

by good fortune, falls to death".

And that's not all, because, immersed as it is in the galaxy ${ }^{93}$ of network, the discourse of hate today also acquires a very particular elusiveness. An elusiveness that - exactly as in the case of cyber-terrorism - is gradually becoming more and more evanescent and incorporeal and that is born essentially from the combination of three fundamental factors:

i) the anonymity, that is that particular filter that - behind the various devices, the accounts, the many possible and imaginative nickname hides the true identity of the users ${ }^{94}$;

ii) the ability of all digitized information to keep for an indefinite period of time and to resurface unexpectedly, causing the relief of

${ }_{93}$ Evident the reference to CASTELLS of which, here, I borrow the expression (2007, passim).

94 To the point that - as pointed out by Steiner's well-known string - on the Internet nobody knows you're a dog! (cf. New Yorker 5th July 1993). 
forgetfulness to fade $e^{95}$, as in the Net everything is omnipresent, everything is now ${ }^{96}$;

iii) the volatility - or more properly the itineracy - understood like the ability of the data to migrate autonomously from platform to platform, transferring itself in contexts also much different regarding those to the inside of which they are generated ${ }^{97}$.

Let us observe, in a historical moment like the one we are experiencing - in which the algorithm dominates ${ }^{98}$ and in which rages that data-ism of which Harari speaks ${ }^{99}$ - any information (positive and/or negative, true and/or false, given and/or subtracted) is subject to being analyzed, decomposed, re-aggregated, de-contextualized and then $r e$ proposed.

Of course, hate speeches are no exception. Indeed! As we can see, the process of $d e$ - and re-contextualization that, continuously, is put in place by algorithms is transformed in its own way into their own involuntary yet valiant ally - undeniable, the discomfort of the philosopher of law, and in general of the jurist, that both in the case of yyber-terrorism and in that of the bate speech is forced to compete with forms of violence that require a careful balance of rights and freedom

95 AMATO MANGIAMELI 2020, 119.

96 On the fusion and confusion between past and present, the observations of VIRILIO 2000 are always relevant and interesting, in part. 118.

97 See GARDAGLIONE, GAL, ALVEZ, MARTINEZ 2015, 13 ss.

98 Among many see ZELLINI 2018.

99 A very singular phenomenon that the well-known historian and essayist defines as the birth of a new religion that is based on and venerates its own data (HARARI, 2018). 
and, towards which traditional regulatory instruments do not always appear appropriate ${ }^{100}$.

Consider, for example, the complex and delicate relationship between the right to privacy and the right to security, as well as the difficulty of reconciling freedom of speech, of thought, expression and press with the protection of moral integrity and image of the individual ${ }^{101}$.

We can also think at the inadequacy of traditional categories and institutions ${ }^{102}$, that - having been developed in the background of a real and national space context - more and more often they are insufficient or completely unable to regulate and repress criminal conduct carried out within that immaterial and acephalous framework that is the Web.

100 As proof of this, it is sufficient to remember that - besides guaranteeing the anonymity of the agent and/or its difficult availability - the electronic cocooning causes the spacetime coordinates to be lost (and therefore the tempus and the locus commissi delicti). Coordinates essential to identify the competence as well as the applicable standard.

${ }^{101} \mathrm{It}$ is interesting to recall that the evaluation of the report freedom of expression and the contrast to hate speech has been the focus of many ECHR rulings. Generally speaking, in the light of the combination of Article 10 of the European Convention on Human Rights (which guarantees freedom of expression) and Article 17 (which, on the other hand, prohibits the abuse of the freedoms recognized by the Convention to undermine its foundations)the ECHR has been guided in the sense of denying the protection of freedom of expression to anyone who promotes values which are in direct conflict with those of the Convention itself. In general, on the balancing of rights/freedoms and the protection of fundamental rights within the European Union, cf. MANGIAMELI 2006.

${ }^{102}$ On the basis of the fact that technological changes inevitably influence the legal order, the question arises as to whether it is still possible to maintain the old conceptual schemes unchanged or whether attempts should be made to adapt them to a new reality, imposed by the overwhelming technological development, not running away from the issue. Cf., ABUNDANT 2017, 41-68; SABELLA 2017, in part. 147; PITRUZZELLA 2017. 
In this sense, it is clear that the way to follow must be based on dialogue and cooperation between the different States. In the knowledge that only thanks to the prediction of common strategies and projects ${ }^{103}$ and through the adoption of legal measures ${ }^{104}$ uniform and shared, it is possible to deal adequately with violence on the Net. A violence that, precisely because widespread, incorporeal and deterritorialized, can be contained only through shared and unanimous legal responses. This, which the European Union has been undertaking for some time and which, even recently, has been confirmed by a series of measures aimed precisely at preventing and combating hate speech and cyberterrorism ${ }^{105}$.

103 Significant and noteworthy: the project Monitoring and reporting on-line hate speech in Europe - eMORE (coordinated, in Italy, by the IDOS Study and Research Centre, which aims to increase the knowledge available on hate speech to implement effective and efficient multistakeholder initiatives to combat crime); the project Coalition of Positive Messengers to Counter Online Hate Speech (which addresses the issue of incitement to online hatred of migrants, refugees and asylum seekers in the $7 \mathrm{EU}$ countries); the No bate speech movement (youth campaign of the Council of Europe against the discourse of hate on the Net, with the aim of combating racism and discrimination and, in general, all the phenomena that manifest themselves in the form of hate speech on the Internet).

104 With regard to the measures taken to ensure security on the Internet and to combat cybercrime, in the European context, may be remembered: Directive 2013/40 of the European Parliament and of the Council of 12 August 2013, on attacks against information systems; Directive 2016/1148 of the European Parliament and of the Council of 6 July 2016 on Measures for a common high level of network and information system security in the Union"; Regulation (EU) 2016/679 of the European Parliament and of the Council of 27 April 2016 on the protection of personal data.

105 Just think of: Directive (EU) 2018/1972 of the European Parliament and of the Council of 11 December 2018 with which the European Code of Electronic Communications was established; European Parliament Legislative Resolution of 17 April 2019, on the proposal for a regulation of the European Parliament and of the Council on the prevention of the dissemination of online terrorist content (COM(2018)640); and Regulation (EU) 2019/796 of 17 May 2019, 


\section{CONCLUSIONS}

Several years ago, in the piéce The Resistible Rise of Arturo Ui, by Bertold Brecht - with his disenchanted and provocative lucidity - warned men to pay attention in view of a possible and unexpected reappearance of violence:

"And you, learn that you need to see

and do not look in the air; action must be taken

and don't talk.

This monster was,

once, to rule the world!

The people extinguished it, but now

let's not sing victory too soon:

the womb from which he was born is still fruitful" 106.

It goes without saying that the German playwright could not have imagined that violence would recur together with ICT and, in particular, between the links of those information and sharing

concerning restrictive measures against cyber-attacks which threaten the Union or its Member States.

106 BRECHT 1963. 
highways that innervate and connect the World Wide Web. But if, from a certain point of view, it is even assumed that Brecht did not expect - and we could not wait - similar developments. Developments that, he was not at all in a position to predict. From another point of view, however, it seems decidedly less obvious, that these same implications were not predicted even by Tim Benrers-Lee who, of the Internet, was the originator and the creator.

Convinced that the Web - before even representing a technological invention - constituted a social invention able to help people to communicate, improving their reticular existence in the world, Benrers-Lee does not seem to have taken into account that its platform of connection and sharing (just like any other means in the hands of man), soon, could become the main theater of violence ${ }^{107}$.

Sometimes praised for the many opportunities it offers, sometimes demonized precisely because of the pitfalls and violence that hides, however, the Internet today represents the plot of our existence ${ }^{108}$. Indispensable aid of all our work activities and not, thanks to the many apps and the various friendly platforms, the Web projects us into a new dimension, within which, everything is immaterial because it is devoid of corporeality. That is to say, in that particular dimension that Floridi defines as info-sphere.

It is a dimension in which ICT does not simply act as a support, but becomes a necessary condition of social well-being, and general

107 VIRILIO shaped trend, which, in fact, affirms: Internet is at once the "worst and the best of things", can became "limitless progress" or absolute catastrophe (2000, 101-103). ${ }^{108}$ So much so that, "for its ability to distribute information in all fields of human activity" it could be compared, for importance, to the electricity grid (CASTELLS 2006, 13). 
development ${ }^{109}$. While social networks, for their part, become "environmental, anthropological, social and interpretative forces" 110 . In the meantime, from the history we pass to the hyper-history and from the archiving we pass to the computing and, that is, to the analysis, to the storage and to the automated association of the information.

Such phenomena reverberate in a profound way also on the violence, that, in fact, assumes those aspects that are proper to the info-sphere: where the only time is that of the simultaneity, where there are fewer spaces and distances, where the most important goods are the data, and where the main agents are the algorithms.

But note: if it is true that violence takes on the characteristics of the context within which it is inscribed, of the means through which it is extrinsic and of the object it strikes, it is equally true that violence is not generated ipso facto by the encounter with ICT and the Web.

Hence, the obvious need - as Eco already suggested - to distance themselves so much from the apocalyptic (that is, from those who express a critical and closed attitude towards the Net and the new technologies, blaming them and almost criminalizing them), so much from the integrated (by whom, adopting a naively optimistic view, does not take into account the risks and pitfalls typical of the Web). In particular, to try to reconcile the need to take advantage of all the advantages that cyberspace offers us and to avoid the possible violent drifts, it is useful to adopt an approach, so to speak, intermediate.

109 See FLORIDI 2017, 4 ss.

${ }^{110}$ CASTELLS, cit., IX. 
An approach, which could be defined as that of the measured users. And, that is, of those who, having at heart the protection of fundamental rights and freedoms and in the light of the need to combat online violence, acts, also in the Net, with that measure that is proper to law and justice. So that, even in cyberspace, can express and realize that Midsein that corresponds to the ontological status of man and the truth of man. An anthropological truth - even before it is juridical - that Saint Augustine with admirable clarity exhorts us to rediscover and reaffirm: "Noli foras ire, in te ipsum redi, in interiore homine babitat veritas" 11 .

\section{REFERENCES}

ABBONDANTE, Fulvia, Il ruolo dei social network nella lotta all'hate speech: un'analisi comparata fra l'esperienza statunitense e quella europea, 41-68, in Informatica e diritto, 1-2/2017.

ALISDAIR, A. Gillespie, Cybercrime: Key Issues and Debates, New York, 2015.

AMATO MANGIAMELI, Agata C., Diritto e cyberspace. Appunti di informatica giuridica e filosofia del diritto, Turin, 2000.

111 2013, XXXIX, 72. 
AMATO MANGIAMELI, Agata C., Arte e/ o tecnica. Sfide giuridiche, Padua, 2012.

AMATO MANGIAMELI, Agata C., Informatica giuridica. Appunti e materiali ad uso di lezioni, Turin, 2015.

AMATO MANGIAMELI, Agata C., Filosofia do direito penal: quatro vozes para uma introdução, Belo Horizonte, 2019a.

AMATO MANGIAMELI, Agata C., Algoritmi e big data. Dalla carta sulla robotica, 101-124, in Rivista di Filosofia del diritto, 1/2019b.

AMATO MANGIAMELI, Agata C., SARACENI, Guido, I reati informatici. Elementi di teoria generale e principali fattispecie criminose, Turin, 2019c.

AMATO MANGIAMELI, Agata C., CAMPAGNOLI, Maria Novella, Strategie digitali. \#diritto_educazione_tecnologie, Turin, 2020.

ARISTOTELE, Politica, trad. it., Milan, 2016.

BALKIN, J. et. al., Cybercrime. Digital Cops in a Networked Environment, New York, 2016.

BALLESTEROS, Jesús, Repensar la par, Madrid, 2006.

BAUDRILLARD, Jean, Simulacres et Simulation, Paris 1981. 
BAUDRILLARD, Jean, Les stratégies fatales, Paris, 1983.

BAUDRILLARD, Jean, Lo spettacolo del terrorismo, trad. it., Milan, 2002.

BAUMAN, Zygmunt, Dentro la globalizzazione. Le conseguenze sulle persone, trad. it., Milan, 2007.

BAUMAN, Zygmunt, Il secolo degli spettatori. Il dilemma della sofferenza umana, trad. it., Rome, 2015.

BECCARIA, Cesare, Dei delitti e delle pene, Milan, 1973.

BENJAMIN, Walter, Per la critica della violenza, trad. it., Rome, 2010.

BOBBIO, Norberto, Diritto e forza, in BOBBIO, Norberto, Studi per una teoria generale del diritto, Turin, 1970.

BOLTANSKI, Luc, Lo spettacolo del dolore, trad.it., Milan, 2000.

BRANDÃO, Cláudio, Significado politico-constitucional do direito penal, in Revista do Instituto de Pesquisas e Estudos, 195-213, 45, 2006.

BRANDÃO, Cláudio, Teoria Jurídica do Crime, Belo Horizonte, 2019.

BRECHT, Bertolt, La resistibile ascesa di Arturo Ui, trad. it., Turin, 1963. 
CADOPPI, Alberto, CANESTRARI, Stefano, MANNA, Adelmo, PAPA, Michele (eds.), Trattato di diritto penale. Cybercrime, Turin, 2019.

CAMPAGNOLI, Maria Novella, Il terrorismo suicida, Rome, 2015.

CAMPAGNOLI, Maria Novella, I nuovi volti del terrore. Dal terrorismo suicida al cyber-terrorismo, Vicalvi, 2017.

CAPOGRASSI, Giuseppe, Il problema della scienza giuridica, Milan, 1962.

CASTELLS, Manuel, Galassia Internet, trad. it., Milan, 2007.

CAVARERO, Adriana, Orrorismo. Ovvero della violenza sullinerme, Milan, 2007.

CERRI, Giovanni, Il linguaggio politico nel "Prometeo" di Eschilo. Saggio di semantica, Rome, 1975.

CHEN, Tom, LEE, Jarvis, Cyberterrorism: Understanding, Assessment, and Response, New York, 2014.

CLAUSEWITZ, Carl, On War, New York, 1943.

CODELUPPI, Vanni, La vetrinizzazione sociale, Turin, 2007.

GULLO, Antonio, Nuove frontiere tecnologiche e sistema penale: alcune note introduttive, in Diritto Penale Contemporaneo, 2/2019, VI-XIV. 
COHEN, Daniel, L'evoluzione del terrorismo contemporaneo nel yyber-spazio, in "Gnosis", 2/2016, 119-127.

COLOMBO, Fausto, Il potere socievole. Storia e critica dei social media, Milan, 2013.

COTTA, Sergio, Perché la violenza? Una interpretazione filosofica, L'Aquila, 1978.

COTTA, Sergio, Perché il diritto, Brescia, 1979.

COTTA, Sergio, Il diritto nell'esistenza. Linee di ontofenomenologia giuridica, Milan, 1991.

D'A GOSTINO, Francesco, Bia. Violenza e giustizia nella filosofia e nella letteratura della Grecia classica, Milan, 1983.

D'AGOSTINO, Francesco, La san₹ione nell'esperienza giuridica, Turin, 1999.

D’AGOSTINO, Francesco, La non violenza del diritto, 233-239, in D'A GOSTINO, Francesco, Filosofia del diritto, Turin, 2000.

D’AGOSTINO, Francesco ,Diritto e giustizia, per una introduzione allo studio del diritto, Cinisello Balsamo, 2004. 


\section{Maria Novela Campagnoli IREFLECTING ON VIOLENCEI ISSN 2675-1038}

D’A GOSTINO, Francesco, "Sanzione penale", Cento e una voce di teoria del diritto, D’AGOSTINO, Francesco, AMATO MANGIAMELI, Agata C. ed., Turin, 2010.

DEBORD, Guy, La Société du spectacle, Paris, 1967.

DERRIDA, Jacques, Autoimmunità, suicidi reali e simbolici. Un dialogo con Jacques Derrida, in BORRADORI, Giovanna, Filosofia del terrore. Dialoghi con Habermas e Derrida, Rome-Bari, 2003.

DEL VIGNA, Fabio, CIMINO, Andrea, DELL'ORLETTA, Felice, PETROCCHI, Marinella, TESCONI, Maurizio, Hate me, hate me not: Hate speech detection on Facebook, 86-95, in ARMANDO, Alessandro, BALDONI, Roberto, FOCARDI, Riccardo, Italian Conference on Cybersecurity, Venice 2017.

EDWARDS, Lilian, WAELDE, Charlotte, Law and Internet, Oxford, 2000.

ENGELHARDT Jr., Hugo Tristram, Manuale di bioetica, trad. it., Milan, 1999.

EUROPOL, European Union, Terrorism Situation and Trend Report, 2019.

ESCHILO, Prometeo incatenato, trad. it., Milan, 1995.

FALCO, Giusi Alessandra, La violenza inapparente nella letteratura francese dell'extrême contemporain, Rome, 2016. 


\section{Maria Novela Campagnoli IREFLECTING ON VIOLENCE I ISSN 2675-1038}

FLOR, Roberto, Cyber-terrorismo e diritto penale in Italia, 325-359, in WENIN, Roberto, FORNASARI, Gabriele, (eds.), Diritto penale e modernità. Le nuove sfide fra terrorismo, sviluppo tecnologico e garanzie fondamentali, Trento, 2017.

FLORIDI, Luciano, La quarta rivoluzione. Come l'infosfera sta trasformando il mondo, Milan, 2017.

GANDHI, Mohandas Karamchand, Teoria e pratica della non violenza, trad. it., Turin, 1996.

GANDHI, Mohandas Karamchand, Antiche come le montagne, i pensieri del Mahatma sulla verità, la non violenza e la pace, trad. it., Milan, 1997.

GARDAGLIONE, Iginio, GAL, Danit, ALVEZ, Thiago, MARTINEZ, Gabriela, Countering online hate speech, Parigi, 2015.

GIRARD, René, La violenza e il sacro, trad. it., Milan, 2008.

HARARI, Yuval Noah, Homo Deus. Breve storia del futuro, trad. it., Milan, 2018.

HEGEL, G.W.F., Lineamenti di filosofia del Diritto. Diritto naturale e scienza dello stato, trad. it., Milan, 2006.

HEIDEGGER, Martin, Lettera sull'umanesimo, trad. it., Turin, 1978. 


\section{Maria Novela Campagnoli IREFLECTING ON VIOLENCE I ISSN 2675-1038}

HEIDEGGER, Martin, Essere e tempo, trad. it., Milan, 2011.

HILDEBRANDT, Mireille, Smart Technologies at the Ends of Law, Northampton, 2015.

HUSSERL, Edmund, Meditazioni Cartesiane, trad. it., Rome, 2004.

KANT, Immanuel, Sopra il detto comune "questo può essere giusto in teoria ma non in pratica", in KANT, Immanuel, Scritti politici e di filosofia della storia e del diritto, trad. it., Turin, 1956.

KERÉNYI, Karol, Miti e misteri, trad. it., Turin, 1979.

KIERKEGAARD, Soren, La malattia mortale, trad. it., Milan, 1947.

LÈVINAS, Emmanuel, Filosofia, giustizia e amore, in Aut-Aut, 1985, nn. 209-210.

LÈVINAS, Emmanuel, L'al di là del versetto. Letture e discorsi talmudici, trad. it., Naples, 1986.

LÉVY, Pierre, Il virtuale, trad. it., Milan 1997.

LOCKE, John, Due trattati sul governo, trad. it., Turin, 1960.

LOMBARI, Marco, ALVANOU, Maria, FONIO, Chiara, a cura di, Terrorismo Suicida, Milan, 2009. 
LOVINK, Geert, Ossessioni collettive. Critica dei social media, trad. it., Milan, 2016.

MAYER-SCHONBERGER, Victor, CUKIER, Kenneth N., Big data. Una rivoluzione che sta trasformando il nostro modo di vivere e già minaccia la nostra liberta, trad. it., Milan, 2013.

MANCINI, Italo, Filosofia della prassi, Brescia, 1997.

MANGIAMELI, Stelio (ed.), L'ordinamento europeo, Milan, 2006.

MANGIAMELI, Stelio, "State, European integration, and globalization. New challenges for constitutionalism." Humanities and Rights Global Network Journal, n², 2019. DOI: https://doi.org/10.24861/2675-1038.v1i1.17

MATHIEU, Vittorio, Ambiguità della violenz̧a, in MATHIEU, Vittorio, Luci e ombre del giusnaturalismo ed altri studi di filosofia giuridica e politica, Turin, 1989, 317-321.

MATHIEU, Vittorio, Perchépunire? Il collasso della giustizia penale, Rome, 2008.

MAROTTA, Gemma, ANTINORI, Arije, Cyberterrorism, in PITASI, A., Webcrimes. Normalità, devianze e reati nel cyberspace, Milan, 2007.

MARAS, Marie-Helen, Cybercrime, Burlington, 2015. 
McGOWAN, Mary Kate, Just Words: On Speech and Hidden Harm, Oxford, 2019

McQUADE, Samuel C., The World of Cybercrime: Issues, Cases, and Responses, Lanham, 2014.

MEHAN, Julie, CyberWar, CyberTerror, CyberCrime and CyberActivism, Cambridge, 2014.

MILGRAM, Stanley, Obbedienza all'autorità, trad. it., Turin, 2003.

MOSLEMZADEH TEHRANI, Pardi, ABDUL MANAP, Nazula, TAJI, Hossein, Cyber terrorism challenges: The need for a global response to a multi-jurisdictional crime, 207-215, in Computer Law \& Security Review, 29, 2013.

NIETZSCHE, Friedrich, Così parlò Zarathustra. Un libro per tutti e per nessuno, trad. it., Milan, 1976.

NIETZSCHE, Friedrich, Al di là del bene e del male, trad. it., Milan, 1977.

PINDARO, Tutte le opere: Olimpiche, Pitiche, Nemee, Istmiche, Frammenti, trad. it., Milan, 2010.

PINO, Raffaella, Il "yberterrorismo": un'introduðione, in "Ciberspazio e diritto", 3/2013, 427-445. 


\section{Maria Novela Campagnoli |REFLECTING ON VIOLENCEI ISSN 2675-1038}

PINO, Giorgio, Discorso razzista e libertà di manifestazione del pensiero, 287-305, in Politica del diritto, 39, 2/2008.

PIOVANI, Pietro, Principi di una filosofia morale, Naples, 1972.

PITRUZZELLA, Giovanni, La libertà di informazione nell'era di Internet, in PITRUZZELLA, Giovanni, POLLICINO, Oreste, QUINTARELLI, Stefano (eds.), Parole e Potere. Libertà di espressione, hate speech e fake news, Milan, 2017.

PITRUZZELLA, Giovanni, POLLICINO, Oreste, Disinformation and Hate Speech: A European Constitutional Perspective, Milan, 2020.

PLATONE, La Repubblica, Rome 1997.

PLATONE, Tutte le opere, Rome, 2009.

RIVA, Giovanni, Selfie. Narcisismo e identità, Bologna, 2016.

SABELLA, Pietro Maria, Il fenomeno del cybercrime nello spazio giuridico contemporaneo. Prevenzione e repressione degli illeciti penali connessi all'utilizzo di Internet per fini di terrorismo, tra esigenze di sicurezza e rispetto dei diritti fondamentali, in Informatica e diritto, Vol. XXVI, 2-2/2017, 139-176.

SANT'AGOSTINO, De vera religione, trad. it., 2013.

SCHMID, Alex P., DE GRAFF, Janny, Violence as Communication: Insurgent Terrorism and the Western News Media, Beverly Hills, CA, 1982. 
SCHMITT, Carl, Teoria del partigiano, trad. it., Milan, 2008.

SOFOCLE, Le tragedie, Turin, 1952.

SZYMBORSKA, Wisława, Odio, in SZYMBORSKA, Wisława, La gioia di scrivere. Tutte le poesie (1945-2009), trad. it., Milan 2009.

TACITO, Publio Cornelio, Agricola, trad. it., Rimini, 2017.

TALIA, Domenico, La società globale e $i$ big data. Algoritmi e persone nel mondo digitale, Soveria Mannelli, 2018.

TESTER, Keith, Moral Culture, London, 1997.

TETI, Antonio, L'arma dell'Isis. Cyber Caliphate per combattere la cyber war, 75-87, in GNOSIS, Rivista Italiana di Intelligence, 2/2015a.

TETI, Antonio, Isis e social Network. Da Twitter a Facebook passando per Twitter e Whatsapp, 75-83, in GNOSIS, Rivista Italiana di Intelligence, 4/2015b.

UNGARETTI, Giuseppe, Ironia, in UNGARETTI, Giuseppe, Vita d'un uomo, Milan, 2016.

VIRILIO, Paul, L'Orizzonte negativo. Saggio di dromoscopia, trad. it., Genua, 1986. 


\section{Maria Novela Campagnoli IREFLECTING ON VIOLENCEI ISSN 2675-1038}

VIRILIO, Paul, La bomba informatica, trad. it. Milan 2000.

VIRILIO, Paul ,Città panico. L'altrove comincia qui, trad. it., Milan, 2004.

VON BALTHASAR, Hans Urs, Gesì, Brescia, 1982.

VON BALTHASAR, Hans Urs, Breve discorso sullinferno, trad. it., Brescia, 1993.

WEIL, Simone, Le pensateur et la grâce, Paris, 1962.

ZAMPERINI, Adriano, Obbedienza distruttiva e crisi dell'azione, in MILGRAM, Stanley, Obbedienz̧a all'autorità, trad. it., Turin, 2003.

ZELLINI, Paolo, La dittatura del calcolo, Milan 2018.

ZICCARDI, Giovanni, Cyber law in Italy, Milan, 2013.

ZICCARDI, Giovanni, L'odio online. Violenza verbale e ossessioni in rete, Milan, 2016.

ZICCARDI, Giovanni, Social media. Uso sicuro di web, messaggistica, chat e social network, Milan, 2017.

ZICCARDI, Giovanni, Il contrasto dell'odio online: possibili rimedi, 37-48, in Lessico di etica pubblica, 1/2018. 